\title{
Analysis of Implementation Total Quality Management at Educational Institutions in Indonesia
}

\author{
Merci Hosang \\ Manado State University \\ hosangmerci@gmail.com \\ Deitje A. Katuuk \\ Manado State University \\ deitjekatuuk@unima.ac.id \\ Viktory NJ Rotty \\ Manado State University \\ viktoryrotty@unima.ac.id \\ Jeffry SJ Lengkong \\ Manado State University \\ jeffrylengkong@unima.ac.id
}

\begin{abstract}
The implementation of total quality management is applied to every educational institution as an effort to improve the quality of education. In this case, it is important to carry out management functions in each educational institution. This article discusses the implementation of total quality management in educational institutions to seek to improve the quality of education in achieving a quality standard in education. Every educational institution should show better quality and be able to compete. This is intended so that educational institutions continue to gain the trust of the public and stakeholders. To continue to get this, it must be improved continuously, both physically and non-physically. So as to make a quality educational institution and guaranteed quality. There are several main things that need to be considered in implementing total quality management in the world of education, namely: continuous quality improvement; determine quality standards, cultural change; changes in the organization; and maintain relationships with other agencies and customers and evaluate the system if anything is not appropriate.
\end{abstract}

Keywords: Educational Management; Total Quality Management; Indonesia

\begin{abstract}
Abstrak: Implementasi total quality management diterapkan pada setiap lembaga pendidikan sebagai bentuk upaya untuk. meningkatkan kualitas pendidikan. Dalam bal ini penting untuk. menjalankan fungsi manajemen di setiap lembaga pendidikan. Artikel ini membahas tentang implementasi total quality management di lembaga pendidikan untuk mengupayakan peningkatan mutu pendidikan dalam mencapai suatu standar mutu dalam pendidikan. Setiap lembaga pendidikan sudah seharusnya menunjuke.ean kualitas yang lebih baik dan mampu bersaing. Hal ini dimaksudkan agar lembaga pendidikan tetap mendapatkan kepercayaan dari masyarakat dan stakeholder. Untuk tetap mendapatkan hal tersebut harus di lakukan perbaikan secara berkelanjutan, baik secara aspek fisik maupun non fisik. Sebingga menjadikan lembaga pendidikan yang berkualitas dan terjamin kualitasnya. Ada beberapa bal pokok yang perlu diperhatikan dalam menerapkan total quality management di dunia pendidikan, yaitu: perbaikan kualitas secara terus menerus; menentukan Standar Mutu, perubahan budaya; perubahan dalam organisasi; dan mempertahankan hubungan dengan lembaga lain dan pelanggan serta mengevaluasi system jike ada yang tidak, sesuai.
\end{abstract}

Kata Kunci: Manajemen Pendidikan; Total Quality Management; Indonesia 


\section{INTRODUCTION}

The demand for quality graduates from educational institutions is increasingly being pushed because of the large amount of competition in the job market. One of the implications of globalization in education is the deregulation that opens opportunities for educational institutions (including foreign universities) to open schools in Indonesia. Therefore, the competition in the job market will be heavier. Anticipating rapid changes and increasingly large and complex challenges, there is no other way for the government in its function as the organizer of development in the field of education and educational institutions to make every effort to increase the competitiveness of graduates and other academic products, which among others, through improving the quality of education.

Efforts to improve the quality of education services are related to how that effort by adopting the term Sismennas in state administration - it is necessary to do both at the level of general policy (strategic), managerial policy, and technical policy (Hardjosoedarmo, 2004). One of them is the managerial policy by implementing integrated quality management (Total Quality Management) to anticipate the rapid global influence or what is often called globalization.

Globalization can result in the loss of national cultural identity, while the ability to survive, globalization is something that cannot be avoided in relations between countries. Many concepts were created by developed countries in the fields of economy, politics, democracy, protection of human rights, etc., management of the environment, up to the concept of good governance related to quality improvement. One of them can be related to how the relationship between quality improvement and good governance practices. Good governance in the context of governance can legitimately be seen from the government system itself and how the government runs. Then accountability can be seen from the existence of the government's political belief mechanism on its actions in using public sources and its behavioral performance. The government in making policies must be based on efficient public services and high public management capabilities. According to Nasution 2005, the problems of implementing good governance can, among others, be due to the lack of public services to the community, low policy capabilities, weak financial management, regulations, and service procedures. highly bureaucratic and inefficient allocation of public resources. This is what hinders the implementation of good governance and the consequences can be fatal, for example, it can make poverty alleviation and/or other important matters not work. The problems with the implementation of good governance, among others, could be due to the lack of public services to the community, low policy capabilities, weak financial 
management, highly bureaucratic regulations, and service procedures and inefficiency in the allocation of public resources. This is what hinders the implementation of good governance and the consequences can be fatal, for example, it can make poverty alleviation and/or other important matters not work. The problems with the implementation of good governance, among others, could be due to the lack of public services to the community, low policy capabilities, weak financial management, highly bureaucratic regulations and service procedures, and inefficiency in the allocation of public resources. This is what hinders the implementation of good governance and the consequences can be fatal, for example, it can make poverty alleviation and/or other important matters not work.

The term quality is a subjective and relative term that can be interpreted in various ways where each definition can be supported by the same good argument. Broadly speaking, quality can be defined as a characteristic of a product or service sector that satisfies consumer needs. Quality characteristics can be measured quantitatively and qualitatively. In education, quality is a successful learning process that creates a pleasant atmosphere and provides knowledge. Customers can be those who directly receive these products and services or those who will later experience the benefits of these products and services.

The notion of autonomy in education has not fully agreed on its understanding and implementation. But at least, it can be understood as a form of delegation of authority such as in the acceptance and management of students and teaching staff/non-academic staff, curriculum development, teaching materials, and determining academic standards. In its application in schools, for example, at least teachers should be given professional rights that have authority in the classroom, and not just as an extension of the bureaucracy.

Therefore, management issues need attention because they have implications for improving the quality of education itself. In the world of business and industry, there is a term known as Total Quality Management (TQM) which is then adopted in the world of education. Some continue to use the same term, namely Total Quality Management (TQM), some are making adjustments to the term Total Quality Education (TQE). Whatever terms are used, the end of the application of these terms is the quality improvement or quality aspects of the better management of an institution, and be it business, industry or education. (Tjiptono, 2003).

\section{RESEARCH METHODS}

This research is a qualitative research which is library research, which is research using books and other kinds of literature as the main object (Hadi, 
1995). The research data was collected by collecting books and journals on Total Quality Management (TQM) which was then selected, presented and analyzed and processed systematically and critically.

Sources of research data consist of (1) primary sources are references that are used as the main source of research reference in which in this study, the primary sources used are books (2) secondary sources are references to support and complement to primary sources which in this study use journals on Total Quality Management (TQM) both national and international journals. The data analysis technique in this study uses content analysis, namely scientific analysis techniques about the message content of data (Muhadjir, 1998).

\section{RESULTS AND DISCUSSION}

In the world of education, improving the quality and quality of education will be largely determined by many aspects, such as teachers, leaders, staff, students, curriculum and teaching and learning processes, financial support, management, and many more. However, when categorized into two major aspects, namely internal and external aspects. Internal concerns all components in the school while internal aspects are aspects that come from outside that support and determine the success of education in an institution. Both will support and support each other in achieving educational goals.

Good and quality school management will be determined by how much support is provided by the environment, community and government in supporting educational activities. Likewise, the success of government and community programs in education must be fully supported by the readiness of teachers, staff and students in carrying out the educational mandate stipulated in the law.

In terms of the quality and quality of education, there is a standard that is determined in the national education standard. The national standards set are standards that have been studied and can be achieved by every educational institution in Indonesia. The concept of national education standardization has implications for improving the quality of education, so it is hoped that the existence of national standards can motivate schools to provide the best service for students in their educational environment.

The actual issue regarding education is actually the area of all educational processes which include the education process from start to finish in an effort to achieve the goal of quality and high quality education. Quality is not only hope and aspiration but must be a real target that must be achieved in the context of continuous improvement. For this reason, Qomar (2012) stated several things that the Indonesian government is starting to do at this time in 
seeking various ways to improve the quality of education with various efforts such as adjustments and improvements to the curriculum, improvement and structuring of the education system in stages in all educational paths, improving the quality of the process. learning, including in terms of the welfare of educators, educational advice and infrastructure as well as good evaluation standards, building educational facilities, setting national standards for educators, using a quality assurance system, tightening accreditation and many more. Quality issues are very important for an educational institution to produce good output, because the more quality graduates are produced, the selling value and interest in entering the educational institution increases. Conversely, if the quality is low, the quality of graduates is low which will result in low interest and absorption in educational institutions. Quality issues are very important for an educational institution to produce good output, because the more quality graduates are produced, the selling value and interest in entering the educational institution increases. Conversely, if the quality is low, the quality of graduates is low which will result in low interest and absorption in educational institutions. Quality issues are very important for an educational institution to produce good output, because the more quality graduates are produced, the selling value and interest in entering the educational institution increases. Conversely, if the quality is low, the quality of graduates is low which will result in low interest and absorption in educational institutions.

\section{TQM and Indonesia's Education Challenges}

TQM or total quality management is a meaning and quality standard in education. Edward Salis 2006 provides a philosophical set of tools for improving quality. It is achieved with a central idea which is manifested in the form of implementation. For every educational institution, quality is a central issue that needs attention. If you hear the term TQM, you will feel inclined to business and industry, but in fact some educational institutions have started to apply certain quality standards with the term Integrated Quality Management.

TQM wants improvement in various ways. Therefore, increasing the quality/quality becomes the main point in managerial as well as the discussion of TQM. Juran demonstrated the three managerial processes of an organization known as the Juran trilogy, namely, planning, control, improvement. (Rivai 2009). The details of the trilogy are as follows:

1. Quality Planning, a process that identifies customers and the processes that will deliver products and services with the right characteristics and then transfers this knowledge to all company partners in order to satisfy the customer. 
2. Quality Control, a process by which products are thoroughly inspected and evaluated, against the needs of the customer. Known problems are then resolved, for example, damaged machines are repaired immediately.

3. Quality Improvement, a process by which an established mechanism is maintained so that quality can be achieved in a sustainable manner. This includes allocating resources, assigning people to complete quality projects, training employees involved in quality projects and generally establishing a permanent structure for pursuing quality and maintaining what has been previously achieved.

Although the concept tends to be financial or financial management, it can be translated into various fields including education. The point is that there is an emphasis on the importance of continuous quality improvement for each product even though the techniques taught are different.

In the business world, quality is customer satisfaction, when translated in the world of education is the satisfaction of the community (stakeholders) with the output of the educational institution itself. TQM is an extension and development of quality assurance. TQM is about creating a quality culture, which encourages all staff members to satisfy customers. 5 Thus, the effort made in education is to ensure the quality of education so that the community and other relevant stakeholders will get the satisfaction of the results of an educational process in educational institutions. certain. Of course, the community and the outside world do not think about the process, but they hope that each output from educational institutions can adapt to the needs that exist in society.

The strategy developed in the use of integrated quality management in the world of education is that educational institutions position themselves as service institutions or in other words, become service industries, namely institutions that provide services according to what the customer wants.

\section{Implementation of TQM in Education}

The word implementation means application; use of implements in work; implementation; workmanship until it becomes materialized; embodiment; and implementation of implementation. Meanwhile, Total Quality Management accordion example to Hardjosoedarmo provides a fairly comprehensive understanding, that TQM is the application of quantitative methods and human knowledge to: 1) improve materials and services that are input to the organization, 2) improve all important processes in the organization and 3) improving efforts to meet the present and future needs of users of products and services. 
In the world of education, TQM leads to customer satisfaction, both internal customers and external customers. Internal customers such as principals, teachers, staff and institutional administrators. Meanwhile, outside offenders such as the community, government and the industrial world. So an institution or educational institution is said to have quality if it is able to provide satisfaction to internal and external customers for the services provided.

There are several considerations that are used as the basis for implementing TQM in educational institutions. Educators must be held accountable for their work in a proactive manner. They must develop a problem-solving process that makes sense and can identify and address the underlying causes. Schools must be able to become pilot organizations and be able to measure what is functioning properly and what is not, so that a good system will be obtained in school institutions. Mulyasa (2007) states there are four main reasons for the adoption of TQM in educational institutions, including:

First, educators must be responsible for their duties and functions, because educators are the main factor for school improvement. Educators must control the problem-solving process that has an impact on the learning environment in schools.

Second, education requires a process of problem solving that is sensitive and focuses on identifying and resolving the main causes that give rise to these problems. All the roots in educational problems are systemic, that is, they come from the root of the problem in the school community and have implications for teaching and learning activities in the school itself.

Third, the school organization should be a model for the learning organization of all organizations.

Fourth, through the integration of TQM in educational institutions, the public can discover why the current education system is not working well.

Based on these reasons, it is clear that the application of TQM in the world of education requires good and professional management, good organizational management and the provision of adequate personnel in carrying out a good process so as to produce quality and high-quality output.

\section{CONCLUSION}

The demand for quality in the field of education is something that cannot be avoided by every institution. This is also a demand for good governance practices in the field of education. To achieve quality, an appropriate methodology is needed for its implementation, and that choice is integrated 
quality management or known as Total Quality Management (TQM) in the field of education, so that an institution is more specialized as an educational institution can run in accordance with the strategic plan. Its implementation requires strategic policies at the national level and managerial policies, both for educational institutions and the public, which can then be followed up with sectoral guidelines in the education sector regarding total quality management. With the rapid development of technology, it also demands the application of technology in education in the information age which is nothing but a form of application of information technology types in educational practice, both at the level of strategic policies, managerial policies, and technical policies. To achieve the quality of education, an approach is needed which includes the need to emphasize a change in perspective (mindset), socialization, assistance and empowerment of elements of state administrators and institutions in the field of education to use technology applications that will support the education management system, as well as other strategic choices, so that all of this can support the realization of good governance and quality, especially in educational institutions.

\section{REFERENCE}

Abu-Duhou, Ibtasam., (2002). School Based Management, School Based Management, Jakarta: Logos.

Bajaj, S., Garg, R., \& Sethi, M. (2018). Total quality management: a critical literature review using Pareto analysis. International Journal of Productivity and Performance Management.

Fatah, Nanang., (2001). Education Management Foundation, Bandung: Youth Rosdakarya.

Fathurrochman, I., \& Apriani, E. (2017). Character Education from the Perspective of Islamic Education in an Effort to Deradicalize Radical Understanding Potensia: Journal of Islamic Education, 3 (1), 122.

Fathurrochman, I., Hariani, D., Hamengkubuwono, H., Arsil, A., Muhammad, A., \& Ristianti, DH (2020). The Development of Student Academic Administration Services in Higher Education. International Journal of Psychosocial Rehabilitation, 24 (8), 4764-4771.

Fathurrochman, I., Ristianti, DH, \& bin Mohamed Arif, MAS (2019). Revitalization of Islamic Boarding School Management to Foster the Spirit of Islamic Moderation in Indonesia. Journal of Islamic Education, 8 (2), 239-258.

Hardjosoedarmo, S. (2004). Total Quality Management, Yogyakarta: Publisher Andi,

Ismail, F. (2018). Implementation of total quality management (TQM) in educational institutions. Scientific Journal of Iqra ', 10 (2). 
Mulyasa, E., (2007). Becoming a Professional School Principal, Cet. 9, Bandung: Youth Rosdakarya.

Munizu, M. (2010). Total Quality Management (TQM) Practices and Their Effects on Employee Performance (Study at PT. Telkom Tbk. Makassar Branch). Journal of Management and Entrepreneurship (Journal of Management and Entrepreneurship), 12 (2), 185-194.

Nasution, MN (2005). Integrated Quality Management, Bogor: Ghalia IKAPI.

Prabowo, S. (2012). Total Quality Management (TQM) in Education. Journal of the Social Humanities (JSH), 5 (1), 72-77.

Prawirosentono, S. (2007). A New Philosophy of Integrated Quality Management in the 21st Century, Jakarta: Earth Literacy.

Qomar, M. (2002). Educational Awareness; A Determinant of Educational Success, Yogyakarta: Arruzz Media.

Ristianti, DH, \& Fathurrochman, I. (2020). Group Counseling Assessment. Deepublish.

Rivai, V, (2009). Education Management; Analysis of Theory and Practice, Jakarta: Raja Grafindo Persada.

Sallis, E. (2006). Total Quality Management in Education, Jogjakarta Education Quality Management: IRCiSoD.

Sfreddo, LS, Vieira, GBB, Vidor, G., \& Santos, CHS (2021). ISO 9001 based quality management systems and organizational performance: a systematic literature review. Total Quality Management \& Business Excellence, 32 (3-4), 389-409.

Sholihah, T., Riadi, I., \& Atanjuani, ES (2020). The conceptual foundation for implementation of the Higher Education Quality Assurance System (HEQAS) at UIN Malang Indonesia. PalArch's Journal of Archeology of Egypt / Egyptology, 17 (4), 2346-2362.

Supriyanto, A. (2011). Implementation of total quality management in the learning quality management system in educational institutions. Journal of Cakrawala Pendidikan, 1 (1).

Sureshchandar, GS, Rajendran, C., \& Anantharaman, RN (2001). A conceptual model for total quality management in service organizations. Total quality management, 12 (3), 343-363.

Sutarto, S., Sari, DP, \& Fathurrochman, I. (2020). Teacher strategies in online learning to increase students' interest in learning during COVID-19 pandemic. Journal of Counseling and Education, 8 (3), 129-137.

Tim Gama Jakarta, Popular Scientific Pocket Dictionary, Jakarta: Gama Press, 2010.

Tjiptono, F. and Anastasia Diana, (2003). Total Quality Management, Yogyakarta: Andi Offset. 
110 | Tadbir : Jurnal Studi Manajemen Pendidikan, Vol. 5, No. 1, 2021

Waldan, R. (2020). Total Quality Management in Islamic Perspective. In ICRHD: Journal of International Conference on Religion, Humanity and Development (Vol. 1, No.1, pp. 259-268). 